\title{
QUEEN'S
UNIVERSITY
BELFAST
}

\section{Employing neo-Durkheimian institutional theory in cross-cultural accounting research}

Philip, L., Alexander, L., Beck, M., \& Simon, M. (2016). Employing neo-Durkheimian institutional theory in crosscultural accounting research. Accounting, Auditing \& Accountability Journal, 29(8), 1270-1293.

Published in:

Accounting, Auditing \& Accountability Journal

Document Version:

Peer reviewed version

Queen's University Belfast - Research Portal:

Link to publication record in Queen's University Belfast Research Portal

Publisher rights

Copyright 2016 Emerald.

This work is made available online in accordance with the publisher's policies. Please refer to any applicable terms of use of the publisher.

\section{General rights}

Copyright for the publications made accessible via the Queen's University Belfast Research Portal is retained by the author(s) and / or other copyright owners and it is a condition of accessing these publications that users recognise and abide by the legal requirements associated with these rights.

Take down policy

The Research Portal is Queen's institutional repository that provides access to Queen's research output. Every effort has been made to ensure that content in the Research Portal does not infringe any person's rights, or applicable UK laws. If you discover content in the Research Portal that you believe breaches copyright or violates any law, please contact openaccess@qub.ac.uk. 


\section{Emerald Accounting, Auditing \&}

\section{Employing neo-Durkheimian institutional theory in cross- cultural accounting research}

\begin{tabular}{|r|l|}
\hline Journal: & Accounting, Auditing \& Accountability Journal \\
\hline Manuscript ID & AAAJ-07-2015-2156.R2 \\
\hline Manuscript Type: & Research Paper \\
\hline Keywords: & $\begin{array}{l}\text { Mary Douglas, Hofstede, Culture, Cross-cultural, Cultural change, Social } \\
\text { relations }\end{array}$ \\
\hline \multicolumn{2}{|l}{} \\
\hline
\end{tabular}

SCHOLARONE ${ }^{m}$

Manuscripts 


\title{
Employing neo-Durkheimian institutional theory in cross-cultural accounting research
}

\begin{abstract}
Purpose

Neo-Durkheimian institutional theory, as developed by the anthropologist Mary Douglas, is proposed as a suitable theory base for undertaking cross-cultural accounting research. Her social theory provides a structure for examining within-country and cross-country actions and behaviours of different groups and communities. It avoids associating nations and cultures, instead contending any nation will comprise four different solidarities engaging in constant dialogues. Further, it is a dynamic theory able to take account of cultural change.
\end{abstract}

\section{Design/methodology/approach}

The paper establishes a case for using neo-Durkheimian institutional theory in cross-cultural accounting research by specifying the key components of the theory and addressing common criticisms. To illustrate how the theory might be utilised in the domain of accounting and finance research, a comparative interpretation of the different experiences of financialization in Germany and the UK is provided drawing on Douglas's grid-group schema.

\section{Findings (mandatory)}

Neo-Durkheimian institutional theory is deemed sufficiently capable of interpreting the behaviours of different social groups and is not open to the same criticisms as Hofstede's work. Differences in Douglasian cultural dialogues in the post-1945 history of Germany and the UK provide an explanation of the variations in the comparative experiences of financialization. 


\section{Originality}

Neo-Durkheimian institutional theory has been used in a wide range of contexts; however, it has been little used in the context of accounting research. The adoption of the theory in future accounting research can redress a Hofstedian-bias in accounting research.

\section{Keywords}

Mary Douglas, Hofstede, cross-cultural, cultural change, social relations. 


\section{Employing neo-Durkheimian institutional theory in cross-cultural accounting research}

\section{Introduction}

There has been significant criticism of Hofstede's approach to understanding and examining culture (see, for example, Baskerville, 2003). The association of nations and cultures is particularly problematic in respect of Hofstede's work as it does not facilitate nuanced analyses of preferences and behaviours of different groups and communities with regards to either within-country or cross-country analyses. This suggests that if accounting researchers are to undertake meaningful analyses of ethnic groups, however conceived, there is a need to draw on a theory (or theories) not subject to the same criticisms as Hofstede and with sufficient subtlety and explanatory power to examine the complexities inherent in crosscultural research.

This Special Issue addresses ethnicity and is "aimed at operationalising ethnicity in accounting and accountability research"; the specific area where we seek to make a contribution concerns "learn(ing) from the manner in which 'humanities scholars' have addressed and executed ethnicity-based research". The proposal of this paper is that neoDurkheimian institutional theory, as developed by the anthropologist Mary Douglas, is able to provide a structure for examining both within-country and cross-country preferences and behaviours of groups and communities. This theory does not assume an association between nations and cultures, and accords with Kanbur et al.'s (2009) belief that "the anthropological optic is useful as a corrective to the methodological nationalism of the social sciences generally and as a way of understanding the complexities of the local” (p. 147). Unlike Hofstede, neo-Durkheimian institutional theory contends that any nation, and indeed any community, will comprise four different solidarities each having distinct beliefs and worldviews which are a product of their different patterns of social relations (see, for 
example, Douglas, 2003). Another important criticism of Hofstede is it is inappropriate to assume cultures will stay constant (Baskerville, 2003). Neo-Durkheimian institutional theory does not make this assumption; rather, it is a dynamic theory that is able to explain cultural change via the interactions between the different solidarities that occur as they engage in continual 'cultural dialogues'.

What is important to note is that this theoretical approach can be used to study groups or communities of all forms. Therefore, whilst it can be drawn on to yield additional understandings of accounting practices in Indigenous communities (see, for example, Chew and Greer, 1997; Greer and Patel, 2000; Jayasinghe and Thomas, 2009; who have previously researched accounting in the contexts of Indigenous Australians and Sri Lankans), its adoption need not be restricted to the study of Indigenous communities, ethnic groups or subaltern communities. In prior empirical studies, neo-Durkheimian institutional theory has been used to understand a very broad range of issues from, for example, terrorism (Douglas and Mars, 2003) to vaccination policy preferences (Song et al. 2014). Cross-country and within-country studies have been undertaken that draw on the theory; for example, Grendstad's (2003) and Spalding's (2000) studies examine political preferences across Nordic countries and ethnic 'antagonisms' within Nigeria respectively. Additionally, Buonfino and Thomson (2007) in their report for the Commission on Integration and Cohesion analysing "what it means to 'belong' in contemporary Britain" (p. 5) judge Douglas's ideas offer nuanced understandings of the dynamics of group memberships, identity and belonging.

At present, the theory has been employed in the field of accounting only to a limited degree with studies having been undertaken by Linsley and Shrives (2009), Moerman and van der Laan (2012) and Linsley and Shrives (2014). The first two of these accounting-based studies focus primarily upon how risk perceptions are constructed according to neo-Durkheimian 
institutional theory in the contexts of the Enron failure and asbestos claims; the third paper draws more widely on the theory examining cultural dialogues occurring in the responses to a discussion paper issued by the Financial Reporting Council.

It is important to note that the prior studies of Linsley and Shrives (2009) and Moerman and van der Laan (2012) do not incorporate Douglas's ideas regarding cultural dialogues and how, within any nation or community, the four different solidarities will be present and interacting. Linsley and Shrives (2014) incorporate the idea of cultural dialogues but to a limited extent. Their paper maps each response submitted to an FRC consultation to one of the four solidarities and analyses how each solidarity is interacting with the other three; however, what they are unable to do is to examine the cultural dialogues that will have occurred as each stakeholder group developed its response and nor can they observe how the dynamics of these cultural dialogues will alter over time within each stakeholder group. Cultural dialogues (as described later in this paper) are a fundamentally important part of neo-Durkheimian institutional theory as they provide the mechanism through which cultural change occurs. In this paper we draw fully on the ideas of cultural dialogues and, in this way, extend the work of Linsley and Shrives (2009), Moerman and van der Laan (2012) and Linsley and Shrives (2014).

This paper first of all specifies key components of Douglas's theory and lays out how the grid-group classificatory structure is composed. This enables us to assert the theory merits serious attention as being suited for undertaking cross-cultural research. Then, to illustrate how the theory can be used in cross-cultural accounting and finance research, a comparative interpretation of the different experiences of financialization in Germany and the UK is provided drawing on the grid-group schema and notions of cultural dialogues.

Financialization experiences in Germany and the UK have been selected to demonstrate the value of neo-Durkheimian institutional theory and to show how the theory can be used as a 
frame through which to view temporal and spatial variations in economic and social relationships in two different countries over the last four decades. The argument proposed is that through this stylised interpretation of the historical experience of financialization in both Britain and Germany, differences in Douglasian cultural dialogues can be identified in this history of the respective countries that can provide an explanation of the variations in the different experiences of financialization.

Financialization has attracted substantial and increasing attention across different social science and humanities disciplines. In turn this has generated a rich and varied set of typologies and conceptualized modalities of financialization. These have been used to describe, analyse, and theorise the different forms of financialization that appear to have occurred across time and space (for example: Krippner, 2005; Lapavitsas, 2011; Pike \& Pollard, 2010). These different modalities offer sometimes contradictorily divergent attempts to theorise the increasing and intensifying role that finance plays in shaping economic, social, and political outcomes in the contemporary world.

The plural nature of work to date on financialization is observable with respect to the different definitions of financialization and the different schools of thought that have evolved (Pike and Pollard, 2010). Financialization definitions fall into two groupings focusing upon either shareholder value or the increasing scope of finance (see for example, Haslam, 2010). Those adopting the shareholder value focus examine the consequences this has for management, strategies and firm performance. The scope of the definitions in the second grouping is broader. Definitions range from Froud et al.'s (2002) and Erturk et al.'s (2008) ideas relating to 'coupon pool capitalism' to Krippner's (2005) definition of financialization "as a pattern of accumulation in which profits accrue through financial channels" (p. 174). The implications of financialization for individuals has been examined by, for example, Langley (2008) and Aalbers (2008) who have been concerned with understanding how 
governments have devolved responsibility (and risk) for financial planning down to the individual.

The array of financialization definitions highlight how wide a spectrum of effects financialization is judged to have had across the economic, corporate and social spheres. Thus far no conceptual framework has been advanced that has successfully integrated these differing approaches and can account for financialization not having been a globally uniform phenomenon (Engelen, 2008). If Douglas's grid-group schema can be used to interpret differing financialization processes across space and in time, and as a means of conceptualising cultural discourse and cultural change both within and between social groups in a way that is sensitive to temporal dynamics, then this can serve to illustrate its potential usefulness for cross-cultural accounting research.

In arguing in this paper that neo-Durkheimian institutional theory can provide an approach for accounting researchers to undertake within-country and cross-country research there are two points to emphasise. First, while we find this interpretation of the different financialization experiences historically convincing, we highlight that it is subordinate in this article to the theoretical aspect outlined. Second, it should be noted the framework is being used heuristically, and necessarily, as an aid to interpretation. This interpretation is performed from the perspective of historical sociology (Fischer, 1995) whereby we emplot "constructed evidence" which, though partial and necessarily incomplete, nevertheless "confronts theory" (Fischer, 1995, p. 20). This implies we are not claiming a definitive interpretation for although there is a historiography (qua history) of financialization, our treatment of British and German history is undertaken to show how such a comparative interpretation might be achieved using neo-Durkheimian institutional theory rather than being a claim to the last word on the Anglo-German experiences of financialization. Further, because we are looking across such an expansive period of time then it is not possible to claim a definitive 
interpretation. The chief contribution of this article is to enable nuanced interpretation of typological variations within a theoretical whole and so articulate with the aims of this Special Issue.

\section{Neo-Durkheimian institutional theory and cultural dialogues}

Neo-Durkheimian institutional theory has been described as "one of the most profound and ambitious bodies of social theory to emerge from within anthropology" (6, 2014a, p. 287).

Douglas's extensive body of work initially stemmed from ethnographic studies undertaken in Africa (see Douglas, 1963) and this lead to the development of the theory over a significant period of time. The theory seeks to describe the connection between preferences, social relations and ways of life. It assumes we are social beings and that ideas of 'selfhood' are formed by reference to others. Hence, preferences are constructed dependent upon how social relations are arranged. Social relations and cultural biases augment one another as "adherence to a certain pattern of social relationships generates a distinctive way of looking at the world; adherence to a certain worldview legitimizes a corresponding type of social relations" (Thompson et al., 1990: 2).

To understand how social relations and cultural biases connect, Douglas developed the now familiar, grid-group typology (Douglas, 1970; 1978; 1986; 1993; 1994; 1997; 1999; 2003; 2004; Douglas and Wildavsky, 1982). This classifies social structures on two dimensions of grid and group commensurate with Durkheim's two dimensions of social regulation and social integration, and with the outcome that four solidarities are distinguished. Each of the four classifications or solidarities (individualist, hierarchist, enclave, and isolate) supports four distinctive ways of life (see figure 1). Because Douglas establishes the four solidarities by reference to distinctive patterns of social relations, then we can understand why she considers it amiss to talk of 'traditional culture' (Douglas, 2004) in its recognition that 
“(g)roup cultural markings are products of the human interactions that form and sustain groups" (Richards, 2009, p. 3).

\section{Figure 1 about here}

This neo-Durkheimian approach helps us explain the different preferences and behaviours of the supporters of each solidarity across a very wide range of issues including, for example: the apportionment of blame, views of time, relevant risks, perceptions of resources and nature, and preferences in respect of regulation. (See, for example, Thompson, 1992, for a summary of the preferences of the four solidarities in respect of a very wide range of issues.) Douglas recognises the typology is open to misinterpretation and stresses that the:

... typology of cultures is derived from cultural biases ... A cultural bias is a point of view, with its own framing assumptions and readily available solutions for standardized problems ... It is a question of a way of life, and the way of life depends ... on the social relations that are entailed (Douglas, 1997, p. 128).

If the form of social relations is hierarchical the high grid-high group configuration entails clearly defined outer and inner boundaries. The strong outer boundary separates insiders (group members) and outsiders who are a potential threat to the group, whilst the strong inner boundaries delineate societal roles. To maintain the boundaries hierarchical societies have systems of punishment should boundaries be transgressed (Heap and Ross, 1992). In this form of society "tradition and respect for authority are features ... and abnormal or anomalous behaviour deemed unacceptable" (Linsley and Linsley, 2010, p. 197) and there is an "integrated status system based on authority" $(6,2011$, p.65). By contrast, in the individualistic (low grid-low group) society or community individuals are "relatively free 
from control by others, (although) that does not mean the person is not engaged in exerting control over others" (Thompson et al., 1990, p. 7). This is a competitive form of society and individuals who fail to prosper find limited support is to be had. This can result in an entrepreneurialism and willingness to bear risk $(6,2011)$.

The social structure in an enclaved solidarity is of the low grid-high group form. The high group element results in a strong exterior boundary, and the low grid facet provides actors with freedom as there is a lack of social regulation. Loyalty to the group is of even greater consequence than in a hierarchical society as there is only an exterior boundary. To buttress the exterior boundary and "to maintain stability within the group (enclaves) identify the outside world as a threat" (Linsley and Shrives, 2009, p. 496). Hence, they will commonly identify the outside world as unjust or unequal. To create sufficient unity in enclaved groups requires members to, in advance, commit to forego "individual choice in favour of commitment to live by collectively agreed practices" $(6,2011$, p. 67). It can be argued that the hierarchists and individualists are slightly fearful of enclaves as potentially they "bring threats of radical change to the fabric of society" (Malsch et al., 2012, p. 96). For this reason the hierarchists and individualists can be willing to collaborate to protect their interests when threatened by enclaves.

The fourth way of life is the isolate (high grid-low group) solidarity. Isolates are in a position where there are strong prescriptions in respect of social regulation and, consequently, there is reduced scope for acting independently. Additionally, they are not a part of a community. Consequently, it is commonly argued they are prone to be "pessimistic ... expecting that attempts to improve their lot will result in failure" (Chai, 1997, p. 53). This implies passivity on the part of isolates, although this need not always be the case as isolates will also develop tactics for 'getting by' $(6,2014 b)$. 
Douglas's four-fold matrix assists in understanding how different patterns of social relations result in different worldviews. Douglas is aware that she is "reducing social variation to a few grand types" (Douglas, 1978, p. 185), but these four basic types are the forms of social relations that have been observed to be stable and recurrent. Therefore, Douglas is arguing that the "limitation in variety should be explained at the level of the most fundamental dimensions of the ordering of relations among people, rather than by locally contingent and case-specific features of context" (6, 2014a, p. 290).

\section{Cultural dialogues and change}

Essential to neo-Durkheimian institutional theory is the notion of cultural dialogues. The theory does not consider nations or communities or other forms of group to be homogenous cultural entities. Therefore, it is not expected that a community or society would exclusively display characteristics connected with one of the solidarities. The four solidarities do not operate in isolation; rather, in any society or community they co-exist. This co-existence between the four solidarities is discordant as each is vying to gather new adherents and endeavouring to win the debate as to the most appropriate "form of life to be led in common" (Douglas, 1997, p. 129). The interactions between the four solidarities are important with cultural dialogues arising as they debate which form of community is preferable with the "adherents to the ... ways of life ... (trying) to impose their interpretations on others and ... to institutionalise their preferred form of social relations" (Verweij, 1995, p. 96).

Consequently, the relationship between the solidarities is dynamic. These wrangles between the four solidarities also serve to remind adherents what each form of life signifies and the tensions between the four solidarities can aid in ensuring they do not become exaggerations of themselves (Douglas, 1993). In this sense Douglas is indicating "that 'culture' is never coherent but always riven with conflict"' (6, 2014a, p. 298). 
Douglas's early versions of the theory presented a static model, and Douglas accepts the static version seemed to map four apparently fixed solidarities with individuals in a submissive role, and this potentially implied the theory was deterministic. But Douglas was aware the theory needed to be able to explain change. That is, it needed to be able to explain how and why the dominant solidarity in any organisation or society may come to be supplanted by a different solidarity and, relatedly, how and why individuals switch commitment from one solidarity to another. The dynamic version explains that individuals may swap allegiance either because they have been expelled from their present solidarity (for example, this might occur in an enclaved community where an individual has transgressed the group boundary) or because that individual's commitment to the solidarity is undermined. The latter situation arises when "successive events intervene in such a way as to prevent a solidarity from delivering on the expectations it has generated, thereby prompting (that) individual to seek more promising alternatives" (Thompson et al., 1990, p. 4). For example, an inherent promise in respect of the hierarchical solidarity is that the community will offer some support to individuals who encounter difficulties; if such support ceases to be available then this may cause an individual to question whether to continue to commit to that solidarity. That is, “(a)s disappointment and frustration set in, people have no option but to try to organise under one of the other elementary forms, thus giving rise to negative feedback" $(6$, 2014a, p. 292) [1].

The direction in which an individual moves as they transfer allegiance will depend on the nature of the events that are provoking the change and the persuasiveness of the arguments that proponents of the other solidarities assemble. As a consequence, in any society one of the solidarities may have greater influence than the other solidarities, but it may also be superseded over a period of time. Knowing which is dominant at any point in time can be useful because it helps explain why the policy solutions of that solidarity are being enacted to 
a greater extent than the policy solutions of the other solidarities. Further, although the four solidarities may have a frictional relationship, they may also make "provisional settlements ... and ... hybrids might arise but also decay" $(6,2014 a$, p. 292). These ideas of cultural dialogues and dynamism are highly important in neo-Durkheimian institutional theory as they allow for, and can explain, cultural change. This ensures that the theory avoids assuming that cultures are unchanging.

A criticism that is sometimes aimed at neo-Durkheimian institutional theory is that it is deterministic. However, what needs to recognised is the theory is asserting that individuals are active agents and the solidarity that achieves primacy only does so as an outcome of individuals' verdicts on what form of life they would prefer. It is our instinctive sociability that leads us to approve the establishment of social institutions that limit our actions and can lay claims over us. In return compensations arise from selecting that way of life.

Consequently, the individual-society relationship should be understood as a collaboration between structure and agency (Douglas, 1999). Individuals can cease lending their support to a particular way of life and transferring allegiance is only possible because individuals have agency.

These discussions indicate that neo-Durkheimian institutional theory is "against ... the methodological timidity of merely piling up local descriptions, (with) Douglas insist(ing) that humanity is one species subject to many of the same basic constraints" $(6,2014 a$, p. 290). These basic constraints, social regulation and social integration, result in a typology where there is limited variation in the different forms of social organisation. The classification provides a structure for the analysis of actions and behaviours associated with the four solidarities (and hybrids of these four) across all types of group or community regardless of geographical setting or time period. The names ascribed to the four solidarities can sometimes be contentious, but these should be understood simply as labels and it is the 
underlying theory that is of paramount importance. Understanding 'cultural markings' by reference to patterns of social relations carries the implication that "loose and lazy notions of ethnic, national, traditional, class cultures cannot describe coherent systems of belief and motivation that drive individual action" (6, 2014a, p. 298). Instead, neo-Durkheimian institutional theory posits that we can understand cultural markings (such as rituals, dress, food classifications, forms of blaming, use of stories) as a product of social organisation and, hence, can recognize them as epiphenomena (Richards, 2009). It is also important to re-state that neo-Durkheimian institutional theory is not subject to the criticisms commonly aimed at Hofstede. These are the criticisms that his approach does not examine cultures from-within, assumes a direct relation between nations and cultures, and assumes cultures are constant. The next section reviews and compares the experiences of financialization in the UK and Germany. The two subsequent sections then examine, on a necessarily broad level, key cultural dialogues in the UK and Germany in the period post-World War Two. This examination of cultural dialogues suggests that the dominant solidarity in each country lost adherents as individuals transferred allegiance from one way of life to another. In the UK the dominant hierarchical solidarity is replaced by a dominant individualistic solidarity whereas in Germany the dominant hierarchical solidarity is replaced by a hybrid hierarchicalenclaved-individualist solidarity. Importantly, overlaying the analysis of cultural dialogues onto the different financialization trajectories of the two countries reveals a strong match in respect of both the UK and Germany.

\section{Comparing the experience of financialization in the UK and Germany}

There is an established consensus that the UK, together with the USA, has "moved furthest in the direction of being truly 'financialized' (Engelen, 2008, p. 114) and that financialization in the UK grew rapidly across the 1980 s and 1990s with its roots being traceable to the 1970s or 
possibly a little earlier (Mollan and Michie, 2012). In the context of firms it has been asserted that when globalization started to take hold and foreign competitors entered the marketplace in the 1970s, UK manufacturing firms experienced a decline in profitability (see, for example, Tweedale 1996; Froud et al., 2000). The threat posed by this change was especially noticeable in respect of car and consumer electronics manufacturers. Froud et al. (2000) propose that the productionist period of the 1980s was then superseded in the 1990s and a second period of financialization commenced with firms in a contest to produce value for shareholders.

Erturk et al. (2008) (see also Froud et al., 2002) argue that a defining characteristic of financialization in the UK was the 'massification' (that is, the increasing amounts) of savings from individual households which were then channelled through a coupon pool[2]. This resulted in innovative financial products being developed; hence, this widened the assortment of coupons being traded. As well as impacting on firms by driving the demand for improved shareholder value, this change also impacted on family units. The key impact on families was that they were forced to take greater personal responsibility for their financial futures and the associated management of risk. Langley has furthered these discussions of the impact of financialization on individuals in the UK by considering the likes of mortgages and consumer credit (see, for example, Langley, 2008). These discussions emphasise the underlying narratives of individual responsibility, while illustrating the linkages between changes in individual behaviours with innovation in the financial markets in the form of, for example, asset backed securities and credit default swaps. Aalbers has also discussed financialization in the context of UK and USA mortgages and securitization, with a focus upon explaining why the "financialization of mortgage markets demand(ed) that not just homes but also homeowners become viewed as financially exploitable" (2008, p. 148). In the UK context 
Aalbers' comments are particularly important because of the, by European standards, relatively high levels of home ownership.

The 'massification' of savings underpinning these financialization waves also had the outcome of significantly increasing the numbers of financial intermediaries. Retail banks were reshaped as they began offering a plethora of products for savings and borrowings, and finance fed on itself (Erturk et al., 2008). In turn this ensured that the financial services industry in the UK continually grew in importance and brought into being what Hall (2009) describes as 'financialized elites' in the City of London. Alongside this rapid increase in financialization in the UK, it has been observed that inequalities have also grown apace (Erturk et al., 2008).

The literature examining the experience of financialization in Germany is less well-known and depicts a very different state of affairs to the UK experience. Jürgens et al. (2000) provide an early account of financialization from the German perspective in which they maintain that by the end of the 1990 s there had been only a limited move towards a shareholder value orientation in Germany, and that this move only began to occur in the mid1990s. That there has been some movement towards financialization since the mid-1990s is indicated by a modest rise in institutional share ownership, concentrated on a very narrow group of German companies including Daimler-Benz, Hoechst, MAN, and Preussag[3]. Consequently, they conclude that, even in comparison to other Continental European countries, Germany moved only marginally towards a shareholder value orientation. They argue that because the German stock market is small in comparison to the size of the economy and only a small proportion of adults own shares, there has not been the same impetus for a shareholder value orientation compared to the UK where "value-oriented investors are major players" (Jürgens et al., 2000, p. 56). Additionally, they suggest that because of bank domination of the German corporate governance system[4] and 
codetermination, shareholder value is not the principal concern of the majority of companies[5].

Deeg (2009) has sought to determine whether non-financial European companies have financialized by considering a different set of factors to Jürgens et al. (2000). Deeg asserts that a financialized company is one which has a focus on shareholder value, a preference for market finance and is listed on a stock exchange. His expectation is that financialization will be observable if: (i) there is a move away from using domestic debt towards using international debt, (ii) there is a decrease in the percentage of loans in total liabilities, and (iii) a culture of listing can be observed in respect of domestic firms. Deeg's analysis of German data for these three factors leads to a similar conclusion to that of Jürgens et al. (2000); namely, that there are only muted signs of financialization in Germany and starting in the mid-1990s[6].

Duenhaupt (2012) provides a comparative study of rentier income[7] in Germany and the USA for the period 1980-2005. The trend of the results for the period 1980-1994 support the claim that financialization had not taken place in Germany in this period as both the wage share and rentier income remain stable. Subsequently, the wage share fell and rentier income rose for the period 1995-2005, which Duenhaupt interprets as indicative of a partial move towards shareholder value orientation in the late-1990s in Germany. Duenhaupt's study extends Epstein and Jayadev's (2005) examination of rentier income in fifteen OECD countries for the period 1978-1999, and Epstein and Jayadev's rentier income trends for Germany are consistent with Duenhaupt's conclusions.

Engelen et al. (2010) and Lapavitsas (2009) provide more recent perspectives on financialization in the German context, with both examining data from the 2000s. All of the measures of financialization employed by Engelen et al. (2010) depict Germany as lagging significantly behind the other four countries in the study. A similar state of affairs holds in 
respect of Lapavitsas' (2009) study, with the German data significantly below the two other sample countries (USA and Japan) in respect of both household financial assets as a proportion of GDP and household liabilities as a proportion of GDP. Engelen et al. comment that their results demonstrate "the limited extent to which financialization has worked itself into the capillaries of German daily life" (2010, p. 65). The outcomes of these two studies provide further confirmation of Jürgen et al.'s (2000) earlier suggestion that financialization has been limited in the German context and, overall, implies that there is consensus in the literature that signs of financialization in Germany only became noticeable from the mid1990s and that the impacts of financialization were much less marked in Germany than in the UK.

\section{Tracing cultural dialogues in the UK}

Malsch et al. (2012) have observed the dominance of the hierarchical and individualistic cultures in Western societies, and it will be argued in this section of the paper that this can be interpreted in the economic and political history of the UK in the post-World War Two years. Here we offer a knowingly stylised historical account which shows the transition from the dominance of a hierarchical solidarity in the approximate period $1945-1970$ as the socioeconomic settlement gradually failed to meet expectations sufficiently (Gamble, 1985). We interpret that some of this shift from the hierarchical was down-grid, with progressive social movements indicating a shift to an enclaved solidarity for some individuals, but ultimately with the individualist solidarity coming to dominate.

The key domestic actions of the Labour government elected in 1945 were expanding welfare provision, actively engaging in organizing the economy and nationalizing approximately twenty per cent of the UK's industrial base (McCormick, 2003). These measures were a response to the severe economic difficulties the UK faced following the war and were implemented with the aim of ending unemployment (Schenk, 1994). The war had had some 
impact upon the patterns of social relations in the UK, but the pre-war dominance of hierarchically-based social structures had largely been sustained (Marwick, 2003). The government actions listed above were hierarchically-oriented with their focus upon regulating and planning (in respect of both the economy and firms) and in providing support for those who may fall upon difficult times (whether because of unemployment, old age or sickness). A Conservative government was voted into power in 1951, and again in 1955, but the fundamental basis for distributional politics remained unchanged as successive governments remained committed to the welfare system, government economic planning, and a commitment to full employment all within, broadly, a Keynsian economic framework (Lloyd, 2002). Although there were political and economic crises during this period, as Childs (2006) notes the 1950 s "came to be regarded as idyllic, the era of the affluent society ... unprecedented prosperity and full employment ... (when) earnings had risen faster than prices" (p. 79).

Hence, one of the fundamental pledges implicit in a hierarchical way of life was met; that society would provide for individuals in return for institutional consent. In the 1950 s this political-economic compact was broadly settled. From a neo-Durkheimian institutional theory perspective, though cultural dialogues by definition cannot have been absent in this period, they were nevertheless relatively subdued. While there were those who espoused an individualistic way of life and argued that governments should not intervene in the economy and called for nationalized firms to be returned to private ownership they were not (yet) culturally dominant (Muller, 1996). Similarly, enclaved voices could be heard such as in the late-1950s in, for example, the arts where writers including John Osborne, Alan Sillitoe, Kingsley Amis and other 'Angry Young Men' were variously attacking or satirising the 'establishment' and the injustices perpetuated against those at the bottom of the hierarchy (Lloyd, 2002; Kalliney, 2001; Kroll, 1961) - but at best they can be said to have merely 
foregrounded the later destabilisation of the Post-War consensus and accompanying changes to social mores that were a hallmark of the 1960 s and the 1970 s.

Criticism of the dominant hierarchical way of life became more pronounced in the UK during the 1960 s and the early 1970 s. Economic crises caused by balance of payments problems in the mid-1960s (and Sterling devaluation in 1967) led to a squeeze on pay, resulting in heightened tension between labour and management (Childs, 2006). From a neoDurkheimian institutional theory perspective, this can be seen as unsettling individuals who may have been supporters of a hierarchical way of life as it constituted a threat to the espoused values of the solidarity and this made them more susceptible to the arguments of the other solidarities. This was not solely a susceptibility to the arguments of the individualistic culture; there was also the potential for disenchanted hierarchists to be persuaded to shift down-grid by enclaved groups. It has been argued that in the USA in this period a similar process occurred connected to a collapse in trust in the establishment, emblematically seen by widespread protests against the Vietman War and increased cynicism of government provoked by the Watergate scandal (Linsley and Shrives, 2009). In the UK support for antiestablishment movements was not as great as in the USA, but enclaved organisations and movements did exist and included groups committed to protecting the environment, to ending gender discrimination and opposing nuclear weapons (Marwick, 2003; Urwin, 1997). Social changes in the 1960s reflected in the enactment of the Abortion Act, Divorce Reform Act and Sexual Offences Act legalizing consensual homosexual sex (Lloyd, 2002; Marwick, 2003) can be interpreted as the weakening of the hierarchical solidarity and increased vibrancy in the enclaved and individualist solidarities.

By the 1970s the previously settled political-economic arrangements of the post-war consensus were breaking down in the face of a "general sense of a worsening economy and declining living standards ... and the break-up of the optimistic consensus" (Marwick, 2003, 
p. 151). Policy frameworks which had been the basis for that earlier period such as the Prices and Incomes Policy were abandoned (Porter, 1996). The oil crisis of 1973 aggravated a struggling economy where the principal features were high inflation, high unemployment and a high balance of payments deficit (Schulze and Woodward, 1996; Lloyd, 2002). By the time of the coalminers strike and the three-day week in 1974 the stability of the post-war years had broken down. The Labour government of 1974-1979 was beleaguered by a stagnant economy, high inflation, and having to request a loan from the IMF in 1976. By the time of the 'Winter of Discontent' in 1978-9 when public sector workers including nurses, ambulance drivers, refuse collectors and gravediggers went on strike, the legitimacy of the previous policy-framework had broken down (McCormick, 2003). In turn, this historical context opened the way for what we interpret to be a fundamental shift in the outcomes of cultural dialogues.

In the run up to the election of April 1979 the Conservative party espoused an individualistic cosmology talking of "reducing the role of government (and) ... enabling everyone to become better off by individual effort" (Childs, 2006, p. 417). During the election campaign the Conservatives implicitly argued that the hierarchical (post-war consensus) solidarity had not delivered on its promises and this was summed up in the now-famous 'Labour isn't working' poster depicting a very long and meandering line of unemployed people. Margaret Thatcher was voted into power in 1979 and enacted changes commensurate with an individualistic culture including: curbing social welfare, deregulating markets, reducing taxation and government spending. Many policies of Thatcher's government were aggressively free-market and pro-business and, eventually, 42 state enterprises were privatised employing c.900,000 people (Foreman-Peck, 2004). The power of trade unions was ruptured, which included the government refusing to concede during the bitter year-long miners' strike in 1984-85. Unemployment benefits decreased (Hall, 2007); the aim being to 
end a 'culture of dependency' that was judged to be smothering enterprise and initiative (Heywood, 2003). The competing cultural dialogues did not stop at the voting in of Margaret Thatcher; if anything we would argue they intensified and this can be seen in the bitter contests for competing visions of British society. Nevertheless, the success of the Conservative party electorally indicates the appeal of a political credo that can be clearly interpreted as being individualistic. In turn it follows that there was a commensurate decline in commitment to, and attractiveness of, the 'old' hierarchical solidarity (Dahrendorf, 1988). The advent of persistently high unemployment caused by sudden de-industrialisation was a kind of social hysteresis; an undoing of the ways of life that had sustained the post-war consensus and its commitment to full employment.

We argue that these shifts in the political, cultural and economic landscape of the UK can be interpreted as indicating the individualistic solidarity had become dominant by the end of the 1970 s and the beginning of the 1980s, and that in broad terms this tallies with the acceleration of financialization in the UK. According to Douglas the individualistic solidarity “explicitly sanctions individual competition" (2004, p. 291). It is an entrepreneurial form of society, where the stimulus motivating individual transactions is to gain resources and "people are expected to go forth entrepreneurially, get new ideas, work hard, and compete for esteem and income" (Douglas, 2003, p. 1358). The "prominent virtues are individual courage, intelligence, perseverance, and success (whilst) (p)ower and wealth are the rewards" (Douglas, 2005, p. 28).

These individualistic endeavours can be seen as congruent with neo-liberalism, and with selfregulation being deemed the most appropriate mechanism for managing markets and the economy. The way the individualistic way of life underpins the financialization process can be conceptualised through the consideration of the three major features of the financialization 
literature: the rise of shareholder value, the construction of financialized elites and the production of inequality, and the growth of financial services.

In the context of companies, if the hierarchical solidarity is dominant then managers should direct and control employees to ensure internal boundaries are maintained. In turn, employees should accept these strictures as the company has a reciprocal commitment to looking after the employees (Hendry, 1999). Managers in this context primarily act as stewards conserving the company's resources and being prudent in their management, to ensure sufficient resources are retained for the future. The aim is for the firm to survive in the long-term as this accords with the time orientation of hierarchists. By contrast, if the individualistic solidarity dominates, the focus of managers should be on wealth creation for the owners and, hence, priority is given to shareholder value. For employees, this individualistic way of life is competitive and retaining employment with the company is dependent upon individual performance. The company's goals are then financially-based and linked through to the overall strategy of maximisation of shareholder wealth. As importantly, the goals are demanding and clearly defined as this enables blame to be traced to specific individuals if targets are not met. The individualistic focus is on the short-term in line with the observation by Douglas and Wildavsky that, in "response to competitive pressure ... he (the individualist) has to be ready to cut his losses, so he does not live by history and tradition. His environment does not encourage him to plan far ahead" (Douglas and Wildavsky, 1982, p. 96).

Financialized elites and inequality also fit into the landscape of the individualistic solidarity. The acquisition of wealth, or symbols of wealth, denotes what it is to be a winner in that solidarity and, as there is no expectation of a safety net, wealth affords some measure of protection should an individual fall on hard times. Thompson (1992) explains it is inevitable that there will be those who prosper and those who sink in this context, as there is no in-built self-balancing mechanism that will even out the inequalities. The people who prosper will be 
the ones who have sufficient talent, resilience, and possibly some good fortune or chutzpah, to successfully navigate the networks that help in being successful. Then there will be those who either do not possess these qualities and are pushed to the fringes because of their lack of success, or who choose not to deploy these attributes as they are not adherents of the individualistic way of life. Inequality is not a sign that the individualistically-based system is malfunctioning; rather, the opposite is the case as it denotes that it is working.

In the individualistic setting it is to be anticipated that financial firms should come to the fore and become pivotal. Individuals need financial firms to provide them with mortgages and loans as the individualistic setting creates a particular set of preferences in respect of styles of consumption. The goods acquired through borrowing symbolically indicate that someone is a winner. They might financially stretch themselves when borrowing but judge it worth the risk of over-borrowing because the extra goods acquired may acquire additional social status and enhanced access to useful networks; hence, there is a return for taking on the risk.

A solidarity becomes dominant as an outcome of individuals' verdicts on what form of life they would prefer (Heap and Ross, 1992). The individualistic way of life has attractions and one of these is that it "implies (emphasis added) an equality of opportunity exists for anyone" (Linsley and Shrives, 2009, p. 499). For example, in the UK during the 1980s the Conservative government could sell the dream of home ownership (a dream that was subsequently perpetuated by the banks and building societies) because an individualistic society implies that anyone, regardless of background, can own a home. Once acquired the home becomes more than just somewhere to live. It becomes a financial asset and a symbol of individual success. For those who were already home owner a more volatile and liquid property market enabled them to seek to trade up to a more expensive home. Of course it is only an appearance of equality of opportunity. For example, the mortgage advisers encouraging home buyers were not trying to democratise the housing market; they were 
looking to gain financially from a transaction (Linsley and Linsley, 2010). The proposition that underpins the individualistic way of life is that by dint of individual effort an individual can achieve whatever they want.

\section{Tracing cultural dialogues in West Germany/Germany}

In the immediate aftermath of World War Two and its attendant horrors of Nazism the experience of German citizens was very different compared to UK citizens, with physical survival and material reconstruction a critical priority (Eichengreen, 2007). The German population also faced the difficult task of creating a country and a polity anew (Conradt, 2009). This difficult task was compounded by the splitting of East and West Germany, and in the context of the Cold War.

In May 1949 the Federal Republic of Germany was formed. Post-1949 the Social Democratic Party (SDP) and ruling Christian Democratic Union (CDU) party, led by Chancellor Adenauer, worked together and converted the business community to the view that industrial relations based on confrontation - frequent in some industries in the pre-war Weimar Republic - should be replaced by social partnership and consensus (Conradt, 2009). The result was that the Federal Republic instituted a series of welfare measures to create what became known as a social market economy. This resulted in a relatively generous welfare system and German governments, both state and national, demonstrated a willingness to intervene in the economy through regulation, the provision of subsidies, and state investment. Although these measures were frequently clad in the reformist language of ordoliberalism, we can interpret this as being indicative of a hierarchical culture[8]. Therefore, we might be tempted to follow Lane and Quack's (1999) suggestion that hierarchy grew to become the dominant cultural dialogue in Germany. However, this ignores that the ideas introduced in post-war Germany went further than the creation of a supportive welfare system and 
government willingness to intervene in the economy. The Basic Law (Grundgesetz) ratified in 1949 was intended to ensure that past errors would not recur and that the new republic would be governed as a human rights-based democracy (Green et al., 2008). This set another tone for cultural debates by creating an initial constitutional impetus for the protection of civil liberties (however narrowly defined) and the promotion of the rights of minority groups [9]. Further, the social market model, developed post-war by Erhard and Müller-Armack, stressed that the market should operate in the interests of society as a whole (Bruff, 2008) and this provided scope for enclaved groups to develop and to be heard. Given the political dominance of industrial groups in the first two decades of the new republic, this did not create an enclaved culture but it nevertheless facilitated support for enclaved ideas.

The gradual influence of enclaved aspects on the socio-political structure of the Federal Republic can be observed in respect of the social capital that eventually developed (Urwin, 1997). Large numbers of citizen groups became affiliated to the mainstream political parties, as did smaller, local action groups seeking to resolve a wide range of issues. Surveys suggest that by the mid-1960s Germans had developed a far greater propensity to engage in social protest and interest than in many other democratic countries (Barnes and Kaase, 1979). The extent of interest groups in Germany after the 1960s has been viewed by sociologists as being indicative of enclaves having gained a significant foothold (see, for example, Helm, 1981). One aspect of the rise in activist-type groups was that the political activism of the New Left in the 1960s encouraged citizens to view protest against government as a means of obtaining reform (Conradt, 2009)[10]. A further aspect was that there was a generational adjustment whereby the so-called '68ers' (people too young to have had experience of the war) were more willing to confront the country's Nazi past, partly because of fears of a revival of authoritarian tendencies (Green et al., 2008). Consensus was central to the German social 
market model and this aided in accommodating the voices of the enclaved-type interest groups alongside the hierarchical solidarity.

The economic result was the German model of social-democratic capitalism and the economic miracle of the 1950s and 1960s. The basis of the German model (which is heavily covered in the "varieties of capitalism" debates) was a combination of strong worker protection, labour representation on the supervisory boards (Aufsichtsrat) of publically limited companies (Aktienggesellshaften), collective wage bargaining, and a dynamic and substantial sector of middle-sized companies (Mittelstand) with significant community rootedness (Hutton, 2003; Green et al., 2008; Busch, 2005). As Busch (2005, p. 126) argues:

\footnotetext{
The characteristics of this model were a comparatively prudent fiscal policy, which (partly due to federal structures) did not experiment with Keynesian demand management; a stringent policy of price stability, carried out by a famously independent central bank, the Bundesbank (which did not shrink even from major conflicts with the government of the day); and a very low degree of labour market unrest, leading to low strike rates and thus supporting the low inflation environment.
}

As can be seen in the quote above there are elements of both enclaved and hierarchical solidarities present in the German model - capitalist businesses with high levels of social welfare and stakeholder involvement in corporate governance. The effect was to insulate West German workers from the more damaging effects of the global economic problems of the 1970s. Although unemployment in West Germany rose during the global recession of the 1970s, overall the economy remained relatively strong (Conradt, 2009). Consequently, we can interpret that Germany was simply not subject to the same intense cultural dialogues that addressed a collapsing economic model as experienced by Britain in the 1970s. The preexisting post war hybrid hierarchical-enclaved solidarity held despite the emergence of 
influential neoliberal critics (see for example, Giersch, 1976)[11]. West Germany's economy continued to maintain, by European standards, relatively low official unemployment rates through to the end of the 1980s despite millions in the conscript army and in apprenticeships. In this context, one critical voice, the sociologist Dahrendorf (1988), was still able to conclude that in Germany "the corporatist culture [has] remained largely intact; whereas in Britain, Mrs Thatcher has, in her nine years as Prime Minister, probably affected a deeper change in social values than any other politician in the post-war period"(1988, p. 194). In the 1990s, however, this settled situation was to change. The unification of West and East Germany caused significant economic hardship, as the moribund economy of the East had to be integrated into the much more dynamic Western economy. This led to a waning of economic success which began to erode the dominance of the German model and impacted on cultural dialogues. For example, the enactment of the second and third laws on the promotion of financial markets (Zweites Finanzmarktförderungsgesetz and Drittes Finanzmarktförderungsgesetz) in 1995 and 1998, brought about some liberalization of German financial markets albeit only in limited form (Vitols, 2003). More significantly, in 2003 Chancellor Schröder began enacting a number of laws (Agenda 2010) to stimulate the economy. Agenda 2010 included some individualistic responses to Germany's problems as these laws cut taxation, and reduced spending on social welfare, including on pensions and unemployment benefit (Conradt, 2009).

From a neo-Durkheimian institutional theory perspective we can interpret that by the 1990s Germany had developed a hybrid hierarchical-enclaved-individualist solidarity. There are two reasons why the previous hierarchical-enclaved hybrid appears to have been modified rather than being usurped. First, the enclaved element of this hybrid moderated the cultural dialogues. Second, there remained a continued desire to maintain a political-economy that insured against authoritarianism taking hold (Freedland, 2012). This fear of authoritarianism 
has been stated in a commitment to a form of latent political consensualism, which Schmidt (1987) described as a 'middle way'. The 'middle way' hypothesis originally stipulated that Germany's multi-veto point polity prevented extreme policy changes leading the country to maintain a position between "extremes of Scandinavian welfare capitalism and AngloAmerican market capitalism” (Schmidt, 2001, p. 1). According to Schmidt (2001) this preference for consensual politics was largely maintained post-reunification even though the underlying policy approach had become more costly in budget terms. Consequently, it appears that some of the commitment to the prior hierarchical-enclaved solidarity switched to the individualist solidarity with both some diagonal movement from hierarchy to individualism and horizontal movement from enclave to individualism occurring; the outcome being a hybrid hierarchical-enclaved-individualist solidarity.

Overall, it can be argued that the cultural dialogues in the UK match with the timing and experience of the UK in respect of financialization, and this is also the case in the German context. Namely, the implanting of the individualistic culture into the hybrid hierarchicalenclaved way of life in Germany in the mid- to late-1990s corresponds with the introduction of financialization in Germany. Further, financialization in Germany was only partial and this also fits with the presence of the German hybrid hierarchical-enclaved-individualist culture. The fusion of the three cultures in Germany implies the hierarchists, enclaves and individualists would all have the opportunity to give voice to their beliefs and opinions, and it is apparent this is the case if we return to the study of Jürgens et al (2000). Jürgens et al (2000) state that in the media debates concerning shareholder value in Germany during the 1990s a limited number of positions can be identified: (i) those who consider a shareholder value orientation as potentially harmful because of an implied short-termism, (ii) those who are critical of a shareholder value orientation because of its associations with unemployment and being to the detriment of social relationships within firms, (iii) those who perceive a 
shareholder orientation as having a potentially beneficial effect upon how companies are managed and (iv) those who are resigned to it becoming increasingly the norm for German companies to adopt a shareholder value orientation. The first response corresponds to the voice of the hierarchists whose time orientation is towards the long-term. The second is the enclaved voice criticising shareholder value orientation for the production of inequities both in creating unemployment and in producing relationship conflicts. The third voice is that of the pro-shareholder value individualist and, finally, there is the (often silent) voice of the isolate who feels powerless in the face of any change. Given the hybrid hierarchicalenclaved-individualist nature of the German culture it is understandable that Jürgens et al (2000, p. 55) contend that shareholder value is an "ambiguous development" in the German context.

In recent times, however, there is evidence that financialization in Germany is advancing, albeit in specific ways that reflect the unique cultural dialogues and indicate that cultural dialogues are always ongoing. The impact of unification led to questioning the appropriateness of the German model for the present era and it has been increasingly possible for large corporations to argue that the labour-settlement at the core of the model is out-dated in a globalized economy (Busch, 2005; Green et al., 2008). Haves et al. (2014) argue that since the 1990s German banks have withdrawn from their traditional role as providers of long-term finance, and have adopted more American investment bank style practices; that there has been a rise in institutional and foreign shareholding in large companies; and that there has been an increase in the role of Hedge Funds and Private Equity. All of these three things are seen to have weakened the pre-existing corporate governance arrangements, including labour protection, and are associated with increased financialization. Similarly, Trampusch (2015) discusses the financialization of German public debt management, concluding that: 
(T)he far reaching consequences of the financialization of public debt management [is vital] to one of the core domains of modern capitalist democracies, namely public budget and finance policy. Among these consequences the most important are the disempowering of old organisations involved in issuing government bonds and debt management, the probable implications for parliamentary control over budget policies due to obscure deals on interest-rate and currency-rate swaps, the empowering of the financial market, governments' double role as regulators of banks and being one of their main clients (Quis custodiet ipsos custodes?) and probable conflicts of interest between monetary policy, fiscal governance and debt management. (Trampusch, 2015, p. 132)

Germany's role in the unfolding Eurozone debt crisis (Hall, 2012), in particular with regard to Greece, is further evidence that the cultural dialogue emerging in Germany is increasingly centred around perceptions of the need to protect German financial interests, even at the expense of notions of European solidarity.

\section{Conclusion}

We have proposed in this paper that neo-Durkheimian institutional theory might be a valuable theoretical framework to adopt in cross-cultural accounting research. It overcomes problems associated with Hofstede's approach as it does not connect nations and cultures, and does not make "heroic assumptions of ethnic homogeneity in historical or political arrangements of societies" (Baskerville, 2005, p 391). In its initial inception the theory presented a static model; however, subsequent developments and the integration of the idea of cultural dialogues have ensured that the theory is capable of explaining cultural change. The emphasis upon groups or communities comprising all four solidarities provides insights into group dynamics that are not evident in Hofstede's work. Cultural dialogues reveal the 
dependencies between the four solidarities as well as the differences. Each solidarity only remains viable because of the existence of the other solidarities and the constant debates they are engaged in present an opportunity for the members of each solidarity to affirm their worldview and to look to win new recruits.

As it is such an expansive (or 'grand') theory then there are parts of it that inevitably remain under debate and need to be developed. The isolate solidarity has often been ignored and it is only recently that its significance is being investigated. A more detailed understanding of the functioning of hybrids is required as there is less discussion of these in the literature than there might be. Additionally, the mechanisms of change are being explored from a range of different perspectives to more fully understand how they operate. Extant empirical research has provided strong support for the theory (as discussed by 6, 2011), whilst there remains a need for more empirical work to be undertaken to augment the extant literature $(6,2014 b)$. Researchers using neo-Durkheimian institutional theory have found it to be useful in a wide range of settings (see, for example, the research assembled in 6 and Mars, 2008). In her own writings Douglas displays this inter-disciplinarity in applying her ideas, for example, to aspects of economics, sociology, and philosophy. As a consequence her work ranges from examining the language of emotions (Douglas, 1995) to deviance and danger (Lianos and Douglas, 2000) to condemnations of poverty (Douglas, 2004). A strength of neoDurkheimian institutional theory is its universality, in that its use does not have to be restricted to studies of accounting practices in ethnic groups or Indigenous communities. It can be applied to all types of groups and communities, and can lend understanding to withincountry and cross-country analyses. A caveat is, however, that the grid-group framework needs to be used with reference to the underlying theory. The comparative study of experiences of financialization in Germany and the UK has been presented to demonstrate the utility of the theory in a relatively demanding context; namely, 
showing how the framework is able to integrate the differing modalities, while retaining an appreciation for the unique variations, of financialization that are seen at different moments in history and in different societies. Within the confines of the space of this paper we have not been able to undertake as detailed a historical analysis of Germany and the UK as we might wish. Sociologically inclined historians (producing "sociological history" as opposed to "historical sociology" to paraphrase Fischer, 1995) might look to examine in greater detail the cultural, intellectual, political and economic history of the two countries in order to achieve a more complete and historically acute account of the comparative histories. This caveat made, our stylised historical interpretation does support the contention that in the UK individualistic attitudes towards the organization of economy and society can be seen to be dominant from the 1980s onwards, and this is the critical period when the intensification of the financialization process can be certainly, clearly and consistently seen. In the Douglasian formulation, the cultural dialogues resulted in the gradual erosion of hierarchical mode of social structure, and a contest thereafter between individualistic and enclaved modes of social and economic organization. This contest was primarily 'won' by a coalition of individualistic social groups and, in turn, this affected the form of financialization that is seen in the UK. In the case of Germany, financialization only began to gain traction from the mid-1990s and in a much more muted form, and the interpretation provided indicates this corresponds to a period when an individualistic outlook began to win some of the policy arguments and so was more prominent in the dialogue. However, in Germany the influence of the individualistic oriented social groups was restrained by being embedded within a long-standing hybrid hierarchicalenclaved culture. Clearly, this interpretation is open to re-interpretation and counterinterpretation, but it nevertheless serves to illustrate how a Douglasian-based analysis can be undertaken in the field of accounting and finance. 
Notes

1. Much of the development of the theory as a dynamic theory is attributable to Michael Thompson. For a more extensive discussion of the dynamics of change see, for example, Thompson et al. (1990).

2. For a full discussion of coupon pool capitalism see: Froud, J., Haslam, C., Johal, S. and Williams, K. (2001). Financialisation and the coupon pool. Gestao \& Producao. 8(3), 271-288. In this paper it is explained that the coupon pool is "not (just) the secondary market in issued ordinary shares ... it includes all coupon investment opportunities, including bonds, venture capital and securitised paper" (p. 276). Further, coupon pool capitalism is "where the pool of new and issued coupons becomes a regulator of firm and household behaviour" (p. 275).

3. Kädtler and Sperling (2008) also identify Daimler-Benz as moving to a shareholder value orientation. They note that for other German owned car assemblers there are significant barriers to shareholder value orientation.

4. That is, banks are an important aspect of corporate governance in respect of the provision of company finance and, in turn, the banks control voting rights via networks of cross-shareholdings and have strong representation on supervisory boards. Jürgens et al. (2000) note some loosening of these networks of cross-shareholdings occurring after the mid-1990s, albeit in a restrained manner.

5. In line with Jürgens et al. (2000), Emmons and Schmid (1998) suggest that German universal banks and codetermination regulations have historically acted as quasi-state institutional means of coordinating individual activities and of achieving social consensus. They argue that this, together with shareholder concentration, reduces the role of the stock market as a coordination and control mechanism.

6. An earlier paper by Deeg $(2005$, p. 175) similarly suggests that "the German system embodies an overall logic of voice with long-term cooperation founded on expectations of reciprocity" which reform efforts during the 1990s sought to maintain, rather than replace. Deeg suggests that given the adherence to this logic, a shareholder-orientated subregime has emerged where the logic of voice has been partially replaced by the logic of exit; without the workings of the main regime being fundamentally altered.

7. Rentier income can be defined in different ways. Broadly, it is income that derives from owning capital or investments. An example of a more clearly specified definition is Epstein and Jayadev's (2005, p. 50) classification of rentier income as: "profits earned by firms engaged primarily in financial activities plus interest income realised by all non-financial non-government resident units."

8. Ordoliberalism is associated with the Freiburg School of German economists who argued that state intervention was necessary to ensure that free markets achieved their full potential (see Ptak, 2004). Ordoliberalism became associated with the idea of a social market economy in later years of Adenauer's chancellorship (1949-1963).

9. These traits became more pronounced under the chancellorship of the Social Democrat Willi Brandt (19691974) who de-emphasised Cold War agendas in favour of a democratisation of German society (see, for example, Kommers and Miller, 2012).

10. For example, in 1983 citizen groups successfully protested against a planned government census on the grounds it was invading private lives and, hence, infringed civil liberties.

11. This is not to say that a pronounced neoliberal faction was absent from German politics. However, the principal neoliberal party, the Free or Liberal Democrats (Freie Demokratische Partei or FDP) historically only received between 5.8 and 14.6 percent of the popular vote in Federal elections from 1949 to 2009. See $<$ http://www.wahlrecht.de/ergebnisse/bundestag.htm> accessed March 2013. 


\section{References}

6, P. (2011). Explaining political judgement. Cambridge: Cambridge University Press.

6, P. (2014a). Elementary forms and their dynamics: revisiting Mary Douglas.

Anthropological Forum: A Journal of Social Anthropology and Comparative Sociology,

24(3), 287-307.

6, P. (2014b). Explaining decision-making in government: the neo-Durkheimian institutional framework. Public Administration, 92(1), 87-103.

6, P. and Mars, M. (2008). The institutional dynamics of culture. Farnham: Ashgate

Publishing.

Aalbers, M.B. (2008). The financialization of home and the mortgage market crisis.

Competition \& Change, 12(2), 148-166.

Barnes, S. and Kaase, M. (1979). Political action: mass participation in five western democracies. Beverly Hills: Sage.

Baskerville, R. F. (2003). Hofstede never studied culture. Accounting, Organizations and Society, 28, 1-14.

Baskerville, R. F. (2005). A research note: the unfinished business of culture. Accounting, Organizations and Society, 30, 389-391.

Bruff, I. (2008). Culture and consensus in European varieties of capitalism. Basingstoke: Palgrave Macmillan.

Buonfino, A. and Thomson, L. (2007). Belonging in contemporary Britain. Commission on Integration and Cohesion.

Busch, A. (2005). Globalisation and National Varieties of Capitalism: The Contested Viability of the "German Model." German Politics, 14(2), 125-39. 
Chai, S. (1997). Rational choice and culture: clashing perspectives or complementary modes of analysis? In R.J. Ellis, and M. Thompson, (Eds.). Culture matters - essays in honor of Aaron Wildavsky. Boulder: Westview Press.

Chew, A. and Greer, S. (1997). Contrasting world views on accounting: accountability and Aboriginal culture. Accounting, Auditing and Accountability Journal, 10(3), 276-298.

Childs, D. (2006). Britain since 1945. Abingdon: Routledge.

Conradt, D. (2009). The German polity. Boston: Houghton Mifflin Harcourt.

Dahrendorf, R. (1988). Changing social values under Mrs Thatcher. In R. Skidelsky, (Ed.). Thatcherism. Oxford: Basil Blackwell.

Deeg. R. (2005). Change from within: German and Italian Finance in the 1990s. In W.

Streek, and K. Thelen, (Eds.) Beyond continuity: Institutional change in advanced political economies. Oxford: Oxford University Press.

Deeg, R. (2009). The rise of internal capitalist diversity? Changing patterns of finance and corporate governance in Europe. Economy and Society, 38(4), 552-579.

Douglas, M. (1963). The Lele of the Kasai. London: Royal Anthropological Institute.

Douglas, M. (1970). Natural symbols. London: Barrie \& Rockliff.

Douglas, M. (1978). Cultural bias. Royal Anthropological Institute, Occasional Paper 35.

Douglas, M. (1986). Risk acceptability according to the social sciences. London: Routledge \& Kegan Paul.

Douglas M. (1993). Emotion and culture in theories of justice. Economy and Society, 22(4), 501-515.

Douglas, M. (1994). Risk and blame: essays in cultural theory. London: Routledge. Douglas, M. (1995). The language of emotions in the social sciences. Greek Economic Review, 17(2), 167-176. 
Douglas, M. (1997). The depoliticization of risk. In R.J. Ellis, and M. Thompson, (Eds.).

Culture matters - essays in honor of Aaron Wildavsky. Boulder: Westview Press.

Douglas, M. (1999). Four cultures: the evolution of a parsimonious model. Geojournal, 47(3), 411-415.

Douglas, M. (2003). Being fair to hierarchists. University of Pennsylvania Law Review, 151(4), 1349-1370.

Douglas, M. (2004). Traditional culture: let's hear no more about it? In V. Rao, and M. Walton, (Eds.). Culture and public action. Stanford: Stanford University Press, pp. 85-109. Douglas, M. and Mars, G. (2003). Terrorism: a positive feedback game. Human Relations, 56(7), 763-786.

Douglas, M. and Wildavsky, A. (1982). Risk and culture: an essay on the selection of technical and environmental dangers. London: University of California Press.

Duenhaupt, P. (2012). Financialization and the rentier income share-evidence from the USA and Germany. International Review of Applied Economics, 26(4), 465-487.

Eichengreen, B. (2007). The European economy since 1945. Princeton: Princeton University Press.

Emmons, W. and Schmid, F. (1998). Universal banking. Allocation of control rights and corporate finance in Germany. Federal Reserve Bank of St Louis Review, 80(4), 19-42. Engelen, E. (2008). The case for financialization. Competition and Change, 12(2), 111-119. Engelen, E., Konings, M. and Fernandez, R. (2010). Geographies of financialization in disarray: the Dutch case in comparative perspective. Economic Geography, 86(1), 53-73. Epstein, G. A. and Jayadev, A. (2005). The rise of rentier incomes in OECD countries: financialization, central bank policy and labor solidarity. In G.A. Epstein, (Ed.). Financialization and the world economy. Cheltenham: Edward Elgar Publishing. 
Erkturk, I., Froud, J., Johal, S., Leaver, A. and Williams, K. (2007). The democratization of finance? Promises, outcomes and conditions. Review of International Political Economy, 14(4), 553-575.

Fischer, C.S. (1995). Historical Sociology and Sociological History: Theory and Practice. European University Institute Working Paper 95/3.

Foreman-Peck, J. (2004). How privatisation has changed Britain, BBC 3, December 2004, [Online]. Available at http://news.bbc.co.uk/1/hi/business/4061613.stm [Accessed 30 March 2012].

Froud, J., Haslam, C., Johal, S. and Williams, K. (2000). Shareholder value and financialization: consultancy promises, management move. Economy and Society. 29(1), 80110.

Froud, J., Haslam, C., Johal, S. and Williams, K. (2002). Cars after financialization: a case study in financial under-performance, constraints and consequences. Competition and Change, 6(1), 13-41.

Gamble, A. (1985). Britain in decline. London: Macmillan.

Giersch, H. (1976). Current problems of the West German economy. Nationalekonomisk Tidsskrift, 114(1), 46-56.

Green, S., Hough, D., Miskimmon, A. and Timmins, G. (2008). The politics of new Germany. Abingdon: Routledge.

Greer, S. and Patel. C. (2000). The issue of Australian indigenous world-views and accounting. Accounting, Auditing and Accountability Journal, 13(2), 307-329.

Grendstad, G. (2003). Comparing political orientations: grid-group theory versus the LeftRight dimension in the five Nordic countries. European Journal of Political Research, 42, 121. 
Hall, P. (2007). The evolution of varieties of capitalism in Europe. In B. Hancke, M. Rhodes, and M. Thatcher, (Eds.) Beyond varieties of capitalism. Oxford: Oxford University Press.

Hall, P. (2012). The Economics and Politics of the Euro Crisis. German Politics 21(4), 35571.

Hall, S. (2009). Financialised elites and the changing nature of finance capitalism: investment bankers in London's financial district. Competition and Change, 13(2), 173-189.

Haves, J., Vitols, S. and Wilke, P. (2014). Financialization and Ownership Change:

Challenges for the German Model of Labour Relations. In H. Gospel, A. Pendleton, and S.

Vitols, (Eds). Financialization, New Investment Funds, and Labour: An International

Comparison. Oxford: Oxford University Press, pp. 148-75.

Haslam J. (2010). The problematics of financialization: critical reflections. Critical

Perspectives on Accounting, 21, 642-645.

Heap, S.H. and Ross, A. (1992). Introduction: Mary Douglas and the enterprise culture. In S.H. Heap, and A. Ross, (Eds.) Understanding the enterprise culture: themes in the work of Mary Douglas. Edinburgh: Edinburgh University Press.

Helm, J. (1981). Citizen initiatives and the growth of voluntary action in Germany. Nonprofit and Voluntary Sector Quarterly, 19(2), 49-61.

Hendry, J. (1999). Cultural theory and contemporary management organization. Human Relations, 52(5), 557-577.

Heywood, A. (2003). Political ideologies. Basingstoke: Palgrave Macmillan. Hutton, W. (2003). The world we're in. London: Abacus. Jayasinghe, K. and Thomas, D. (2009). The preservation of indigenous accounting systems in a subaltern community. Accounting, Auditing and Accountability Journal, 22(3), 351-378.

Jürgens, U., Naumann, K. and Rupp, J. (2000). Shareholder value in an adverse environment: the German case. Economy and Society, 29(1), 54-79. 
Kädtler, J. and Sperling, J. (2008). Logics of bargaining in the German automotive industry. In I., Erturk, J. Froud, S. Johal, A. Leaver, and K. Williams, (Eds.) Financialization at work. London: Routledge.

Kalliney, P.J. (2001). Cities of Affluence: Masculinity, Class, and the Angry Young Men. MFS Modern Fiction Studies, 47(1). The Johns Hopkins University Press, 92-117.

Kanbur, R., Rajaram, P. K. and Varshney, A. (2009). Ethnic diversity and ethnic strife: an interdisciplinary perspective. World Development, 39(2), 147-158.

Kommers, D. and Miller, R. (2012). The Constitutional Jurisprudence of the Federal Republic of Germany. Durham, NC: Duke University Press.

Krippner G. R. (2005). The financialization of the American economy. Socio-Economic Review, 3, 173-208.

Kroll, M. (1961). The Politics of Britain's Angry Young Men. Social Science JSTOR, 15766.

Lane, C. and Quack, S. (1999). The social dimensions of risk: bank financing of SMEs in Britain and Germany. Organization Studies, 20(6), 987-1010.

Langley, P. (2008). Financialization and the consumer credit boom. Competition \& Change, 12(2), 133-147.

Lapavitsas, C. (2009). Financialised capitalism: crisis and financial expropriation. Research on Money and Finance Discussion Paper Number 1. [Online]. Available at http://www.soas.ac.uk/rmf/papers/file47508.pdf [Accessed 20 January, 2012].

Lianos, M. and Douglas, M. (2000). Dangerization and the end of deviance: the institutional environment. British Journal of Criminology, 20(2), 261-278.

Linsley, P.M. and Linsley, A. P. (2010). Cultural theory of risk and the credit crisis. Journal of Risk and Governance, 1(3), 193-206. 
Linsley, P. M. and Shrives, P. J. (2009). Mary Douglas, risk and accounting failures. Critical Perspectives on Accounting, 20(4), 492-508.

Linsley, P. M. and Shrives, P. J. (2014). Douglasian cultural dialogues and the Financial Reporting Council complexity project. Critical Perspectives on Accounting, 25(8), 757-770.

Lloyd, T. (2002). Empire, welfare state, Europe: History of the United Kingdom 1906-2001. Oxford: Oxford University Press.

Malsch, B., Tremblay, M. S. and Gendron, Y. (2012). Sense-making in compensation committees: a cultural theory perspective. Organization Studies, 33(3), 389-421.

Marwick, A. (2003). British society since 1945. London: Penguin.

McCormick, J. (2003). Contemporary Britain. Basingstoke: Palgrave.

Moerman, L. C. and van der Laan, S. L. (2012). Risky business: socializing asbestos risk and the hybridization of accounting. Critical Perspectives on Accounting, 23, 107-116.

Mollan, S. and Michie, R. (2012). The City of London as an international commercial and financial center since 1900. Enterprise and Society, 13(3), 538-87.

Muller, C. (1996). The Institute of Economic Affairs: undermining the post-war consensus. Contemporary British History, 10(1), 88-110.

Pike, A. and Pollard, J. (2010). Economic geographies of financialization, Economic Geography, 86(1), 29-51.

Porter, D. (1996). Government and the economy. In R. Coopey, and N. Woodward, (Eds.). Britain in the 1970s. London: UCL Press.

Ptak, R. (2004). Vom ordoliberalismus zur sozialen marketwirtschaft, stationen des neoliberalismus in Deutschland. Opladen: Leske \& Budrich.

Richards, P. (2009). Against ethnicity: ring composition and conflict resolution. FocaalEuropean Journal of Anthropology, 54, 3-15.

Schmidt, M. (1987). The politics of the middle way. Journal of Public Policy, 7(2), 135-177. 
Schmidt, M. (2001). Still on the middle way? Germany's political economy at the beginning of the twenty-first century. German Politics, 10(3), 1-12.

Schulze, M.S. and Woodward, N. (1996). The emergence of rapid inflation. In R. Coopey, and N. Woodward, (Eds.). Britain in the 1970s. London: UCL Press.

Song, G, Silva, C. L. and Jenkins-Smith, H. C. (2014). Cultural worldview and preference for childhood vaccination policy. Policy Studies Journal, 42(4), 528-554.

Spalding, N. (2000). A cultural explanation of collapse into civil war: escalation of tension in Nigeria. Culture \& Psychology, 6(1), 51-87.

Thompson, M., Ellis, R. and Wildavsky, A. (1990). Cultural theory. Boulder, Colorado: Westview Press.

Thompson, M. (1992). The dynamics of cultural theory and their implications for the enterprise culture. In S.H. Heap, and A. Ross, (Eds.). Understanding the enterprise culture: themes in the work of Mary Douglas. Edinburgh: Edinburgh University Press.

Trampusch, C. (2015). The Financialisation of Sovereign Debt: An Institutional Analysis of the Reforms in German Public Debt Management. German Politics, 24(2), 119-36.

Tweedale, G. (1996). Industrialization and deindustrialization in the 1970s. In R. Coopey, and N. Woodward, (Eds.). Britain in the 1970s. London: UCL Press.

Urwin, D. (1997). A political history of Western Europe since 1945. London: Longman. Verweij, M. (1995). Cultural theory and the study of international relations. Journal of International Studies, 24(1), 87-111.

Vitols, S. (2003). From banks to markets: the political economy of liberalization of the German and Japanese financial systems. In K. Yamamura, and W. Streeck, (Eds.). The end of diversity? Prospects for Japanese and German capitalism. New York: Cornell University Press. 


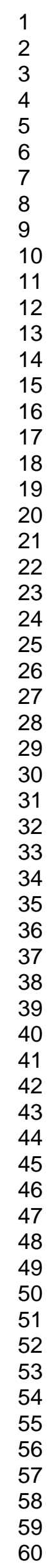




\section{Figure 1: The grid-group framework}

\begin{tabular}{|c|c|c|}
\hline 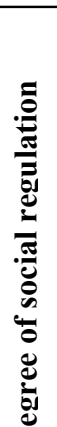 & $\begin{array}{l}\text { Isolate } \\
\text { Strong social regulation } \\
\text { Weak social integration } \\
\text { Social ties weak } \\
\text { Limited scope for self-determination } \\
\text { May see the world as capricious } \\
\text { Potentially passive } \\
\text { Looking to 'get by' }\end{array}$ & $\begin{array}{l}\text { Hierarchy } \\
\text { Strong social regulation } \\
\text { Strong social integration } \\
\text { Defer to tradition and authority } \\
\text { Rules and regulations important with } \\
\text { interactions being regulated } \\
\text { Mechanisms for dealing with internal } \\
\text { and external boundary transgression } \\
\text { Little toleration for unconventional } \\
\text { behaviour } \\
\text { Confident in planning for the long-term }\end{array}$ \\
\hline & $\begin{array}{l}\text { Individualist } \\
\text { Weak social regulation } \\
\text { Weak social integration } \\
\text { Belief in market mechanisms } \\
\text { Preference for self-regulation } \\
\text { Belief in unconstrained activity } \\
\text { Failure deemed personal responsibility } \\
\text { Limited support in the event of failure } \\
\text { Risk not wholly but provides opportunity } \\
\text { and the expectation is profits will exceed } \\
\text { losses in the long-run }\end{array}$ & $\begin{array}{l}\text { Enclave } \\
\text { Weak social regulation } \\
\text { Strong social integration } \\
\text { Strongly committed to the group } \\
\text { Disloyalty to the group may result in } \\
\text { exclusion or expulsion } \\
\text { Collective memory emphasises group } \\
\text { boundary by recollecting exceptional } \\
\text { acts of loyalty or disloyalty } \\
\text { Tendency to idealism } \\
\text { Perception of the world as fragile }\end{array}$ \\
\hline
\end{tabular}

Group dimension - degree of social integration

Source: adapted from Douglas (1982, 1986, 2004) 